\title{
Forging Urban Development through Literacy Improvement for Less-developed States Study of Jharkhand, India
}

\author{
Ar. Rajan Chandra Sinha, Dr. Satyaki Sarkar, and Dr. Bimal Chandra Roy
}

\begin{abstract}
India is experiencing significant urban growth. Though demographers use varying definitions of "urban" and "rural" but their figures indicate that about 28 percent Indians already live in urban areas and the percentage is on an upward gradient. Following the current trend it may be expected that the urban centers in future will function to an even greater degree than today as the social, economic and demographic heart of the region. Hence better functioning cities and towns are thus crucial to government strategies for eradicating regional disparities and for creating a more equitable society. They are also vital to restoring and speeding up economic growth and widening its impact, and creating a sustainable urban development process.

Amongst various indicators that are determinants to such urban development, education and more precisely literacy, hog the limelight. Education has long been regarded as laying the foundation for development of a region and mankind at large. As per Population Census of India 2011, the Literacy rate of India has shown as improvement of almost 9 percent. It has gone up to $\mathbf{7 4 . 0 4 \%}$ in 2011 from $\mathbf{6 5 . 3 8 \%}$ in 2001 , thus showing an increase of 9 percent in the last 10 years. Yet there remains a gap. To mitigate the like of it, India has been supporting and promoting the development of education across its landmass as an essential component of their development efforts. Infact literacy, as reflected in Human Development Reports is an important social entitlement, a key determinant of well-being and a goal of urban and human development. But such initiatives have not borne fruits in all parts of the country and especially for states like Jharkhand which still remains one of the most backward states of the country.

Jharkhand, the newly constituted and a severely backward state in India is the study area for this paper. The state alone provides nearly 30 percent of the mineral resources of the country and boasts of nearly 60 lakh urban population. But the urban development process in this state shows a total lack in planned initiatives and control. A further look reveals that an integrated approach to urban development is much sought after by the inhabitants of the state since the complexity of urban functions and their interdependence on various parameters is increasing by leaps and bounds. Infact, one of the prime determinants here is the lack of sound human resource due to low literacy level since literacy here had always taken a backseat. In the state the literacy rate as per the 2001 Census is $54.13 \%$ is below the national average of $65.38 \%$. During April 2006, as the government figure published, the total number of school drop out is abysmally high and the rate was registered at 47 per cent portraying a sordid state of affairs.
\end{abstract}

Rajan Chandra Sinha is a PhD research scholar in the Department of Architecture, Birla Institute of Technology, Mesra, Ranchi, India

Satyaki Sarkar is working as an Associate Professor in the Department of Architecture, Birla Institute of Technology, Mesra, Ranchi, India

Bimal Chandra Roy is an Assistant Professor in the Department of Architecture, Birla Institute of Technology, Mesra, Ranchi, India
Hence, it is apparently felt that urban development for such a potentially rich resource based state often faces hurdles due to low literacy level.

With this background, in this paper, the author tries to analyse the impact of literacy in urban development process within a delineated administrative area, especially with regards to less developed states like Jharkhand. This paper will also discuss as to how strengthening of literacy in a state like Jharkhand will bring urban development in the state which will ultimately culminate in overall development for the state.

Keywords - Urban Development, Literacy, Less Developed States, Correlation, Regression

\section{Human Development And Literacy}

Human development may be viewed as the process of achieving an optimum level of health and well-being which surfaces in various context and may be determined broadly based on physical, social, educational, economic, and cultural components. These components are intrinsically related with one another and cumulatively determine the level of development of a region. But only few of these are considered in the Human Development Index, a composite scale that has three dimensions: life expectancy at birth, adult literacy rate along with mean years of schooling, and income as measured by real gross domestic product per capita. Like all onedimensional scales that attempt to measure multiple complex variables, it is flawed by inherent inaccuracies, but it is nonetheless a useful comparative measure of the well being of a population.

Education, the most crucial investment in human development, is an instrument for developing an economically prosperous society and for ensuring equity and social justice. Literacy is the base for equipping oneself with various learning skills and serves as a stimulus for further learning. Literacy also acts as the pivot for individual and societal development and plays an important role in poverty reduction. Based on this, literacy promotion is the heart of Education for All movement (EFA) and also supports the achievement of other related international initiatives including United Nations Education for Sustainable Development (UNESD) and Millennium Development Goals (MDGs).

\section{LITERACY STATUS OF INDIA}

The 15th official census in India was published in the year 2011. It has been observed that for India, literacy is the main foundation for social and economic growth. When the British 
rule ended in India in the year 1947 the literacy rate was just $12 \%$. Over the years, India has changed socially, economically, and globally. After the 2011 census, literacy rate India 2011 was found to be $74.04 \%$. Kerala is the only state in India to have $100 \%$ literacy rate. It is followed by Goa, Tripura, Mizoram, Himachal Pradesh, and Maharashtra, Sikkim. The lowest literacy rate in India is seen in the state of Bihar (Censusinfo 2011).

According to Human Development Report 2011, India ranked 134. Progress seen on Human Development Index (HDI) with an $18.65 \%$ increase in index value between 2000 to 2011 . However inequality remains a concern with $28.7 \%$ loss in the HDI value on account of inequalities. Improvements seen in literacy rates for both males and females in Indian context. While male literacy rates improved by 6.84 Percentage Points female literacy rates improved by 11.76 Percentage Points. Significant gender gap in outcomes however persists

\section{LITERACY SCENARIO IN JHARKHAND}

As has been discussed education as has been perceived by many authors is the basis of development of human capital. Like other states of India, the basic education in Jharkhand starts from the age of five years onwards. With the level of literacy being poor in Jharkhand there isn't also significant improvement in the state in the level of human well being especially with regard to life expectancy, infant mortality, nutritional status of children, etc.

The State of Jharkhand has 24 districts with the subdivision of 2 more districts. The Level of Urbanization is recorded at $24 \%$ as per 2011 Census. In Jharkhand State the literacy rate as per the 2011 Census is $66.41 \%$ which is below the national average of $74 \%$. While the female literacy rates for Jharkhand went up to 55 per cent by 2011 from a low of 39 per cent in 2001 , the male literacy rates increased only by 10 points from 67 per cent to 77 per cent over the same period.

Jharkhand has an inadequate educational infrastructure, exacerbated by increases in population. The dropout rates in Jharkhand are very high compared to the national average. At the primary level, the average drop out ratio in Jharkhand has decreased from 15.79 per cent to 12.62 per cent (DISE, 201112).The average drop out ratio at primary level among the boys (13 per cent) is higher than for the girls (12.23 per cent) in the state.

The districts having higher literacy rates than the State average of are Purbi Singhbhum, Dhanbad, Ranchi, Bokaro and Hazaribagh. Pakur district has the least literacy rate (30.54\%) followed by Sahebganj (37.91\%) and Garhwa $(39.39 \%)$. The teacher student ratio in Jharkhand is 1:60, which is above the reasonable size of student per teacher that a teacher would attend each child efficiently in the class. This hampers the quality of education.

\section{Comparative Assessment Of Literacy Status Of JHARKHAND With DEVELOPED STATES IN INDIA}

'Literacy' is a prime mover of state economy as more literacy propels people to try out more avenues to sustain livelihood based on knowledge. Significant development of many districts of few overall developed states in India like
Maharashtra, Punjab and Tamilnadu can be correlated to better literacy rate brought about by literacy campaign, programme and strong educational infrastructure. Jharkhand is way behind with the cumulative state average being lower than national average. For few districts of Jharkhand like Pakaur, Chatra, Shahibganje, Garhwa, Latehar and Palamu, this ranges between $48 \%$ to $56 \%$ where the national average is around $74 \%$. Comparatively, this indicator is evenly distributed for all districts of Maharashtra, Punjab, West Bengal and Tamilnadu.

Low education attainment is a barrier to development as people do not venture into new roads of economy leaving their traditional economic base. Moreover, this lessens migration and migratory flow. Infact, it may be underlined that 'Literacy rate' for Jharkhand is one of the prime causes for severe backwardness of certain districts and low development profile of the state as a whole.

\section{V.DePENDENCE Of Literacy On OVERall DeVelopment}

Every indicator, on which development index of a region depends, has a correlation amongst each other. The indicator may be positively or negatively correlated i.e. increase in the level of one parameter may increase or decrease the level of other in question, but all the most, they have some level of relation.

A correlation carried out between Literacy rates of Jharkhand, Tamilnadu, Maharashtra, West Bengal and Punjab with demographic indicators like level or urbanisation, level of migration and workforce participation of respective states furnishes data that 'Literacy rate' is positively correlated for all states which suggest that it is one of the prime determinants of urbanisation. When Literacy rate is correlated with migration for respective states, it shows a negative value except West Bengal where the data shows that migration is mostly intrinsic in character, confined within the districts and adjoining ones. Correlation value of 'Workforce participation' is positive for all states under consideration as increased literacy leads to increased human resource but with limited work opportunities, work participation rate decreases. The graphical data further suggests that for Jharkhand, increase in 'Level of Urbanization' can be achieved by increasing the literacy rate which will further lead to increase in migration.

A regression analysis carried out between Literacy rates of Jharkhand, Tamilnadu, Maharashtra, West Bengal and Punjab with level or urbanisation of respective states furnishes data that 'Literacy rate' and 'Percentage district population immigrated' which have high correlation with 'Level of Urbanization', also has a significant level of significance for the same. The values of 'Literacy rate' is highest for the state of West Bengal, followed by Jharkhand, Maharashtra and Tamilnadu thereby suggesting that 'Level of Urbanization' is dependent on the determinant and increase in level of one will necessitate the increase in level of other. 'Percentage district population immigrated' has only got a significant level of significance with Literacy rate for the state of Tamilnadu only and is insignificant for other states under consideration. Amongst all states under consideration, the state of Jharkhand also has a high positive correlation of 'Literacy rate' with 'Level of Urbanization' and the level of significance value is 
significantly high for individual and group value though the 'total' value is comparatively low thereby showing that increase in 'Level of Urbanization' for the state will affect 'Literacy rate' positively to some extent and increase in one will lead to partial rise of another.

\section{The Strategical InPUTS}

Therefore there is a need for a concerted effort to increase the level of literacy in the state of Jharkhand as this increase will have multiplier effect on other sectors of demography including, level of urbanization, level of migration and workforce participation. To organize this development, strategies needs to be made in the light of :

- Participatory approach through panachayti raj institutions in management of educational institutions.

- Adoption of national education standards.

- Augmentation of resources for school infrastructure improvement under Public Private Partnerships.

- Improvement in teacher student ratio.

- Initiating job oriented courses to have better attendance in educational institutions.

- Massive upgradation of primary sector education needs through construction of new buildings.

- Delinking intermediate education and strengthening degree education.

- Imparting distance education, networking between open and formal education.

- Monitoring effective implementation of statewide educational programmes.

\section{CONCLUSION}

The status of education has a very dismal picture in Jharkhand. It has not been deprived of schemes being formulated under national policy but yet could not able to transform the educational scenario. There may be many reasons for that. One can clearly see the prevailing regional, social and gender gap in the state in terms of accessibility to education. Literacy rate is the important indicator, which narrates where our state stand in human development index does. For the state of Jharkhand, analysis reveals that Literacy rate is correlated with so many indicators when compared on demographic platform. When the same is being compared for developed states in India, the picture is more prominent with the revelation that a Literacy rate is a significant contributor to development of a region. Hence there is a need for a concerted approach to develop the Literacy status of the state of Jharkhand. The same can be achieved by adopting feasible strategies for growth and development of the sector which will further develop the urbanization level of the state.

\section{REFERENCE}

[1] Bhagat, R.B. (2011); Emerging Pattern of Urbanization in India, Economic and Political Weekly, (34):10-12.

Government of India, (2011); Census Provisional Population Totals. http://www.censusindia.gov.in/2011provresults/prov data products jharkhand.html

[2] Mohan Rakesh. (1996); Urbanisation in India: Patterns and Emerging Policy Issues in The Urban Transformation of the Developing World, Edited by Josef Gugler, Oxford University Press.
[3] NUEPA (2013); Elementary Education of India - Progress towards UEE http://www.dise.in/Downloads/Publications.

[4] Prakash Amit (2001); Jharkhand: Politics of Development and Identity, Orient Longman, Hyderabad.

[5] Pratham. (2012); Annual Status of Education Report. http://www.pratham.org/M-31-7-Reports.aspx

\section{Biographical notes:}

Rajan Chandra Sinha is a $\mathrm{PhD}$ research scholar in the

Department of Architecture, Birla Institute of Technology, Mesra, Ranchi, India. He is currently working as an Assistant Professor in the Department of Architecture, Birla Institute of Technology, Mesra, Ranchi, India. He graduated in architecture with a post graduation in urban planning. His area of interest includes housing and urban planning. He has a few research publications in his area of interest.

Satyaki Sarkar is working as an Associate Professor in the Department of Architecture, Birla Institute of Technology, Mesra, Ranchi, India and is an expert in the field of industrial and urban planning. He has more than ten years of teaching and research experience. He completed his post graduation in city planning from IIT Kharagpur, India. He received his PhD from Jadavpur University, India.

Bimal Chandra Roy is an Assistant Professor in the Department of Architecture, Birla Institute of Technology, Mesra, Ranchi, India.. He graduated in architecture with a post graduation in urban planning. $\mathrm{He}$ received his $\mathrm{PhD}$ from BIT Mesra, Ranchi. His area of interest includes industrial planning and urban planning. He has a voluminous research publications in his area of interest. 